\title{
Symbolism in The Crying of Lot 49
}

\author{
KONG Li-Xia \\ Henan Institute of Education, Zhengzhou, China
}

\begin{abstract}
The Crying of Lot 49 (1986) is written by Thomas Pynchon, a famous American postmodern novelist. This novel reflects the characteristics of the postmodern literature, and it is a model for the postwar American literature. In the novel, Pynchon employs a large number of codes, symbols, scientific terms, historical allusions, secret languages, and various metaphors, which make the plot of this novel very obscure. Thus, interpretating the symbolic meanings of these codes, allusions, and metaphors can help the readers to understand the deep meaning of this novel, the writer's intention, the modern American society, and furthermore, to introspect ourselves as well as the modern business world.
\end{abstract}

Keywords: Thomas Pynchon, The Crying of Lot 49, symbolism

\section{Introduction}

The Crying of Lot 49, first published in 1966, is written by Thomas Pynchon, a famous American postmodern novelist. It tells a bizarre story of Oedopa's quest for the truth of the real estate giant Pierce Inverarity's mysterious legacy. The novel is very obscure. Seemingly it is a detective novel with a labyrinthine plot, but in fact it reveals a range of complex issues associated with people's inner world and the outside material world. And it exposes people's spiritual poverty in modern society. Also it can be seen as a critique of the contemporary American society. This novel reflects the characteristics of the postmodern literature, and is a model for the postwar American literature. Shortly after its publication, it won the Richard and Hilda Rosenthal Foundation Award. In the novel, Pynchon employs a large number of codes, symbols, scientific terms, historical allusions, secret languages, and various metaphors, which make the plot of this novel more bewildering. Thus, interpretation of these codes, allusions, and metaphors can help the readers to understand the writer's intention as well as the deep meaning of the novel.

Next is the tentative interpretation of the symbolism in this novel.

\section{The Symbolic Meaning of the Title}

At the first sight, the title of the novel The Crying of Lot 49 seems very queer. "Cry”, "lot”, and " 49 " do have their special meanings in the text. "Cry” means, firstly, weep-Oedipa’s silent weep for her beloved country, her forlorn America, because the result of her quest is that she has found an abandoned world of the poor, which is unknown by society. Secondly, it refers to the auctioneer's peddling at the end of the novel.

The dictionary meanings of "lot” are: a large number (quantity), one or a number of goods (in the auction), a

KONG Li-xia, associate professor, Foreign Languages Department, Henan Institute of Education. 
piece of land (for a particular purpose), balloting, fate or luck, etc.. In the novel, "lot” appears several times, sometimes refers to the parking lot, and sometimes refers to fate. Until the end of the novel, it refers to the groups of the auction. The change of the meaning is like a road maze, which lures readers to explore the mystery along with the protagonist.

The number "49" has profound meanings too. First, it makes people think of 1849, the year of California Gold Rush and immigration. The gold camps in the west were in the uninhabited place, which was far away from the government, and was in the sate of autonomy and anarchy. It heralds the outbreak of the American Civil War fighting for democracy and freedom; therefore, “49" symbolizes people's expectations for the new world, the new order, and the eagerness to communicate with each other. Second, at the end of the novel the auctioneer "Passerine spread his arms in a gesture that seemed to belong to the priesthood of some remote culture; perhaps to a descending angel. The auctioneer cleared his throat. Oedipa settled back, to await the crying of lot 49" (Pynchon, 1986, p. 183). Here "49" reminds us of the Christian Pentecost, when the Holy Spirit descended to Christ's followers 49 days after his crucifixion. This means the author expects God to save human being, to save the world in chaos.

\section{The Greenish Dead Eye of the TV Tube}

At the opening of the novel, when Oedipa learns that she is specified the testamentary executor of the estate of the late Pierce Inverarity, there is such a description "Oedipa stood in the living room, stared at by the greenish dead eye of the TV tube, spoke the name of God, tried to feel as drunk as possible” (Pynchon, 1986, pp. 9-10). Here the author uses "greenish dead eye" to describe TV set, intending to show Oedipa's survival environment: the materialistic society full of greed and desire. The word "green”, in English culture, refers to envy, that is, people's envy of what they lack, and it also suggests the US dollar. The word "dead" symbolizes people's psychological state of confusion in consumer society. And “drunk” indicates Oedipa's psychological escape, trying to get rid of spiritual pain by anesthesia.

Such a description at the beginning of the novel leads readers into the chaotic state of the American society in the 1960s. Pynchon does not directly describe American social and political unrest, but shows it by various underground organizations, extremist groups, and various people who are deprived of the inheritance rights of the traditional culture of the United States, such as ethnic minorities, homosexuals, the poor, the madman, and the underground groups. The mysterious Tristero underground postal system represents the marginalized social groups which rebel against the authority. They try to prove their existence by setting up their own organization. The US government, on behalf of the authority and the order, has no power to prevent the destruction of these fringe groups. Pynchon also suggests in the novel that this underground society is the real America.

\section{Entropy and Maxwell's Demon}

Rudolf Clausius, a German physicist, first stated the basic ideas of "The Second Law of Thermodynamics" in his book The Mechanical Theory of Heat (1879), and in 1865, he introduced the concept of entropy. In the 20th century, the law of entropy was gradually extended to observe and explain social phenomena. According to the theory, in an isolated and closed system, the entropy value will only increase, and the matter and energy will dissipate irreversibly from the available to unavailable, from the valid to invalid, and from the orderly to 
disorderly. The entropy of the world always tends to the maximum, and eventually the effective energy which can be used to do work does not exist on the earth. The temperature everywhere will reach equilibrium, so the whole universe will be in the state of "heat death", that is, the eternal silence of death.

Pynchon studied engineering physics at Cornell University, and because of this experience, he frequently uses a great number of scientific and technical terms in his works. In his short story "Entropy” (1967), Pynchon applied the Second Law of Thermodynamics to social observation. He thought with the increasing of entropy in human society, mankind maybe is heading for the "heat death"; therefore, it is imperative to promote understanding and cooperation between people in order to resist the worsening social chaos. In The Crying of Lot 49, Pynchon used "entropy” as a metaphor. It symbolizes the social degradation, people's blind pursuit for power and money, their confusion, depression, pain, and void. The higher the entropy value becomes, the less information is transferred. With the relentless increasing of entropy, communication becomes less, humanity is being lost, and the world will be doomed.

Maxwell's “Demon” is a famous ideal experiment proposed by the Scottish physicist, James Clerk Maxwell. In his book Theory of Heat (1871), Maxwell conceived there exists a demon which is able to sort molecules, control the motion direction of the hot and cold molecules, and then reduce entropy. However, Maxwell's "Demon" is only a scientific hypothesis, and it cannot solve the "heat death" of universe.

Pynchon also repeatedly mentions Maxwell's "Demon" in The Crying of Lot 49. For example, in a conversation with Oedipa, Nefastis explained that "Entropy is a figure of speech, then, a metaphor. It connects the world of thermo-dynamics to the world of information flow. The Machine uses both. The Demon makes the metaphor not only verbally graceful, but also objectively true” (as cited in Pynchon, 1986, p. 106). To solve this problem, Nefastis mentioned that "Communication is the key" (as cited in Pynchon, 1986, p. 105). However, in modern materialistic society, interpersonal communication becomes more and more difficult for young people. Their spirits are thrown into the wilderness alone. Maxwell's "Demon” is only an ideal assumption, so human being has not the ability to solve the problem of entropy.

\section{Mysterious Code: WASTE (We Await Silent Trystero Empire)}

In the novel, WASTE is the secret code of the underground postal organization which Oedipa wants to investigate. It means "We Await Silent Trystero Empire” (Pynchon, 1986, p. 169). But it pronounces like "waste" (garbage), so the intention of the author is evident. On the one hand, WASTE refers to the mysterious underground postal system; on the other hand, a symbol of the capitalist business world. In the society to be treated as rubbish, human nature is alienated by substance. People always exist in a state of loneliness, anxiety, pain, confusion, and fear. Like the characters described in the novel, they rely on alcoholism, drug addiction, madness, and watching endlessly meaningless TV programs to get themselves intoxicated so as to escape from the social reality. Most ironically, even the psychiatrist Dr. Hilarius becomes insane. We can infer that the author's purpose here is to expose the underside of American dream.

\section{Oedipa Maas and Her “Tower"}

The name "Oedipa" evokes the tragic Greek hero Oedipus, who is fated to murder his father and marry his mother. Oedipus is tormented by the question of man's place in the universe, and faced with religious, political, 
and moral problems. He is forced to continue his quest to the very end, but unfortunately, his quest to interpret the Delphic prophecies leads to his downfall. Likewise, Oedipa, like a detective, tries to solve the puzzling riddle posed by Pierce's will, but learns the truth is not easy to discover and finds nothing till the end of the novel. "Maas" suggests "mass" in Newton's law of universal gravitation, a formless piece of material free to be moved and shaped by the forces acting upon it. Just as Oedipa's experiences during the course of quest, there are different forces acting upon her. Breaking the social shackles, like getting rid of the earth gravity, is always a human dream.

The commercial operation mode of modern society, as the invisible forces, puts the individual into a vulgar, monotonous framework of life. Limited in a fixed position just like machine parts, the individual lives a dull, automotive life recognized by society. As a housewife in materialistic society, Oedipa's life looks exactly the same everyday, buying daily food and necessities, going to the party, and reading popular magazines. The quest for the secret of Pierce's property provides her an opportunity to see an abandoned world of rubbish, in which there are homeless people, drug addicts, paranoids, dissidents, the unemployed, beggars, prostitutes, etc.. The quest also lets Oedipa go out of the mechanical life circle to try a new life, to search for the meaning of life, and to feel the freedom of human nature so that her life can always "keep it bouncing” (Pynchon, 1986, p. 178). However, in a commercialized world, Oedipa is predetermined to find nothing about the mystery. At the end of the novel, Oedipa comes to the auction room, and wants to see the representatives of Trystero. But the novel ends in the crying of the auctioneer dramatically, and Oedipa's quest has become a fruitless adventure.

In the novel, Pynchon uses "tower" as a symbol to indicate Oedipa's living condition. Oedipa feels that she is "Rapunzel-like role of a pensive girl somehow, magically, prisoner among the pines and salt fogs of Kinneret, looking for somebody to say hey, let down your hair... But dauntless, perhaps using one of his many credit cards for a shim, (Pierce) he'd slipped the lock on her tower door and come up the conch-like stairs...” (Pynchon, 1986, p. 20). Here "credit card" symbolizes the power of money in the materialistic society. It can even unlock the door on the enchanted tower. The "tower" in the text is invisible, and it is hidden in Oedipa's heart. The world of entropy described in the novel is just like a tower, a closed system. Due to the lack of communication, people living in their closed world become paranoid, confused, and will ultimately die meaninglessly. Oedipa is such an ordinary person living in this invisible tower.

Besides, there are many other descriptions about "tower" in the novel, which symbolizes that Oedipa lives in a closed system. In a dream, Oedipa is "such a captive maiden, having plenty of time to think, soon realizes that her tower, its height and architecture, are like her ego only incidental: that what really keeps her where she is is magic, anonymous and malignant, visited on her from outside and for no reason at all” (Pynchon, 1986, p. 21).

The tower also symbolizes Oedipa's entrapment by materialistic society, for "the tower is everywhere" (Pynchon, 1986, p. 22) and "... all that had then gone on between them had really never escaped the confinement of that tower” (Pynchon, 1986, p. 20).

In the process of Oedipa's quest for the mystery of Pierce's will, she finds the situation is changing and getting more and more strange. When she uncovers a layer of the mystery, there will be another mystery and more possibilities. She falls into the layers of fog, trying to solve the mystery, but finds that she is trapped in it more deeper. Later, many clues she has found do not make any sense. What frustrates Oedipa most is that Tristero organization might just be a joke made by Pierce, for "He might himself have discovered The Tristero, and 
encrypted that in the will, buying into just enough to be sure she'd find it. Or he might even have tried to survive death, as a paranoia; as a pure conspiracy against someone he loved” (Pynchon, 1986, p. 179). So Oedipa will never solve the riddle and never escape that invisible tower.

After experiencing various confusion and chaos of postmodern society, Oedipa loses her marriage, her love, her sense of belonging, and her hope for life. She can no longer return to her previous life. Metzger, her lover, abandons her, and her husband Mucho becomes addicted to hallucinogens called LSD. Oedipa's lost love and her failed marriage symbolize people's failure to find order in the chaotic society, and their failure of attempting to explain the meaningless world. Finally, Oedipa finds that she can not even stay awake and falls into pessimism. She sighs, “... I was hoping forever, for love; my one extra-marital fella has eloped with a depraved 15-year-old; my best guide back to the Trystero has taken a Brody. Where am I?” (Pynchon, 1986, p. 153). She "hoped she was mentally ill...” and thinks “... Oh God, was the void. There was nobody who could help her. Nobody in the world. They were all on something, mad, possible enemies, dead” (Pynchon, 1986, p. 171). This is the result of Oedipa's attempt to break free the shackles of that invisible tower.

\section{Conclusions}

Pynchon's literary creation is rather ingenious, and it is a major challenge to the traditional novel. The symbolism of his works is to provide readers with more space of imagination and interpretation. Reading his novel can help us to understand the American society comprehensively , and then to introspect ourselves as well as the modern business world. Besides, his postmodern narrative techniques and black humor bring inspiration to the reading public. When interpreting his works, we should keep an open mind and recognize that the purpose of the subversion expressed in postmodern novels is not to destroy the existing world, but to liberate the repressed personality, to dispel the hierarchical social order, and to release more free space for humanity.

\section{References}

CHEN, S. D. (2007). On the labyrinth of entropy, polysemy and indeterminacy in The Crying of Lot 49. Foreign Literature Studies, (1), 128-132.

Clausius, R. (1879). The mechanical theory of heat. London: Macmillan Publishers Ltd..

KONG, L. X. (2007). Interpretation of the allusions and symbols in The Crying of Lot 49 (《拍卖第49批邮票》中的隐喻与意象

解读). Journal of China University of Water Resources and Electric Power (Philosophy \& Social Science), (3), 72-74.

LV, H. (2003). From order to chaos: On entropy in Pynchon's novels (从秩序到混沌一论品钦作品中的摘主题). Journal of China

Foreign Affairs University, (4), 88-93.

Maxwell, J. C. (1871). Theory of heat. London: Longmans, Green, and Co..

O’Donnell, P. (1991). New essays on The Crying of Lot 49. Cambridge: Cambridge University Press.

Pynchon, T. (1986). The crying of lot 49. New York: Harper \& Row, Publishers, Inc..

SUN, W. J. (2005). Seeking the meaning of being lost: A study of the theme of quest in post-modern novels from Thomas Pynchon's works (追寻失落的意义一从托马斯·品钦的作品看后现代主义小说的追寻主题). Contemporary Foreign Literature, (4), 74-79.

WANG, X. L. (2006). The study of American black humor novels (美国黑色幽默小说研究). Shanghai: Shanghai Foreign Language Education Press.

YE, H. N. (2003). The kaleidoscope like life and the heat death oriented history: On Thomas Pynchon's concern about man's fate as reflected in his novel $V$. (生活的万花筒，历史的热寂观一评品钦的长篇小说《V.》中的忧患意识). Journal of Shanghai Normal University, (5), 52-57. 